\title{
Graptophyllum pictum (L.) Griff. (Syn: Justicia picta Linn.) and its Effectiveness: A Well-Known Indonesian Plant
}

\author{
Feda Makkiyah',*, Eldiza Puji Rahmi ${ }^{2}$, Rika Revina ${ }^{2}$, Tiwuk Susantiningsih', Yuni Setyaningsih'
}

Feda Makkiyah ${ }^{1, *}$, Eldiza

Puji Rahmi², Rika Revina², Tiwuk Susantiningsih ${ }^{1}$, Yuni Setyaningsih ${ }^{1}$

'Faculty of Medicine, Universitas Pembangunan Nasional Veteran Jakarta, INDONESIA.

${ }^{2}$ Department of Pharmacy, Universitas Pembangunan Nasional Veteran Jakarta, INDONESIA.

\section{Correspondence}

\section{Feda Makiyah}

Faculty of Medicine, Universitas

Pembangunan Nasional Veteran Jakarta, INDONESIA.

E-mail: fedaanisah@upnvj.ac.id

History

- Submission Date: 25-11-2020;

- Review completed: 16-12-2020;

- Accepted Date: 02-03-2021.

DOI : 10.5530/pj.2021.13.106

Article Available online

http://www.phcogj.com/v13/i3

\section{Copyright}

(c) 2021 Phcogj.Com. This is an openaccess article distributed under the terms of the Creative Commons Attribution 4.0 International license.

\begin{abstract}
Graptophyllum pictum (L.) Griff., a shrubby stove plant, has been used traditionally to treat various diseases. This review summarizes the up-to-date data about its phytochemistry and pharmacological properties and provides a perspective and direction for future research. The phytochemical analysis of $G$. pictum revealed the presence of flavonoids, steroids, glycoside, tannins, saponin, chlorophyll, nontoxic alkaloid, and anthocyanin. Meanwhile, the pharmacological analysis revealed that this plant possessed various activities such as antimicrobial, immunomodulatory, antioxidant, anti-inflammation, anti-analgetic, woundhealing, anti-hemorrhoid, anti-diabetic, and estrogenic effects. However, most of its pharmacological activities were based on the crude extracts and the bioactive compounds responsible for the bioactivities have not been well identified. A further detailed investigation in phytochemistry to identify the bioactive compounds and to investigate the mechanism action of its bioactivities is required. Moreover, a toxicology study is also needed to develop a standardized formulation of $G$. pictum preparation and to fulfill the requirements of modern phytomedicine.

Key words: G pictum, Indonesia, Pharmacological, Activities.
\end{abstract}

\section{INTRODUCTION}

Over the past century, chemical drug development has transformed the world's health care system. Nevertheless, according to the World Health Organization (WHO), about $80 \%$ of the world's population still relied on natural resources for health maintenance, especially in Africa, Asia, and Latin America. ${ }^{1-26}$ Plants are the most affordable and easily accessible source of raw materials for drug development. They have been traditionally used to treat pathologic conditions or to improve health conditions since hundreds or even thousands of years ago. This ancient medication knowledge has been passed on through generations to generations to keep it in daily life practice as a promising source to defeat diseases, either in the form of traditional preparations or as plant-based active compounds.

As one of the tropical countries, Indonesia has the second biggest potential medicinal plant resource after Brazil. Among more than 40,000 medicinal plants that are used in the world, at least 30,000 of them can be found in Indonesia which reflects almost $90 \%$ of medicinal plants in Asia. ${ }^{27,28}$ This local heritage in traditional medicine was collected by the experience of ancient people only using the patient as a subject of experiment throughout. Hence, it contains many materials worthy of further research to collect scientific data to confirm the claims of folklore medicinal plants for its efficacy and safety to fulfill the modern standards of therapeutic agents. Moreover, among thousands of medicinal plants in Indonesia, only 45 have been certified as Standardised Herbal Medicine and 21 plants have been developed as Phytomedicine.
Graptophyllum pictum L Griff or popularly known as caricature-plant, is a medicinal shrub belong to the family of Acanthaceae. It is most likely native to New Guinea and then extensively spread to India, Mexico, United States, Ghana, Bolivia, and Asia. Currently, it is easily found in some regions in Indonesia and locally known as Daun Ungu, Daun Wungu. Graptophyllum pictum has been used widely to treat many diseases such as wound healing, hemorrhoid, antipyretic, analgetics, and menstrual problems. ${ }^{22}$ There was a previous review of the biological activities of G. pictum, ${ }^{29}$ however, a comprehensive review of the present knowledge is needed to provide the perspectives and directions for future research and potential applications. In this review, we document an updated and complete overview of the botany, phytochemistry, traditional uses, and pharmacological activities of G. pictum. Moreover, the present knowledge obtained mainly from experimental studies was critically assessed to provide evidence and justification for local traditional uses of G. pictum and to propose future research prospects and potential therapeutic uses for this plant.

\section{METHODS}

We searched PubMed and Google Scholar with the term Graphtophyllum pictum, Handeleum, daun ungu, daun wungu among publishing studies between 1990 until 2020. All related review articles, original articles, case reports were analyzed. Selection Criteria. We included articles published in English or Indonesia. Two reviewers (S.T and S.E) independently evaluated the relevance of the retrieved articles by title and abstract. The studies 
that were not related were excluded. Two independent researchers (S.T and S.E) categorized eligible articles. Information from the articles was tabulated and classified according to mechanisms, and results.

\section{RESULTS}

By searching the electronic database, 50 potential articles were identified. The full text of 39 articles was obtained. Most were published from Indonesia (46 of 50; 92\%) (Takayama et al., 2011; Kimura and Sato, 2012; one was published in Japan, two was published in India, Fourteen articles were published in English (28\%) and the rest in Indonesian $(72 \%)$. Six articles were excluded because the article was incomplete (4), the article was about the food coloring effect of G pictum (2).

\section{VERNACULAR NAMES}

Graptophyllum pictum is commonly known as Joseph's coat in English, ${ }^{29}$ daun prada, puding in Malaysia, ${ }^{21}$ Kaala-aduusa, Ysjudemaram India, and Guacamari, Camagua, Guacamayo in Cuba. ${ }^{22}$ Meanwhile, in Indonesia, this plant has different names such as Daun Ungu; Daun Putri, Dangora (Ambon) Kabi-Kabi (Ternate); Demung, Tulak, Wungu (Java); Daun Temen-temen, Handeuleum (Sunda); Karotong (Madura). ${ }^{2}$

\section{BOTANICAL DESCRIPTION}

The characteristics of these plants are the erect standing tree, purple to green leaves. It can grow until 2 meters; the widest leaf is $25 \mathrm{x} 11 \mathrm{~cm}$ with a shiny surface. The flower's color is a dark red and the fruit's color is brownish-purple.

\section{TRADITIONAL USES}

Traditionally, the leaves and/or flowers of G. pictum is considered an emollient, resolvent, laxative, diuretic, and anti-inflammatory., ${ }^{9,12}$ In Cuba, the plant is prescribed in the treatment of earache, sores, swellings, and wounds. ${ }^{22}$ The Indonesian used it to treat tonsillitis, abscess, and rheumatism. ${ }^{2,9}$ Herbarium Amboinense on the eastern and central Indonesian plants mentioned that it has been used to treat breast engorgement and breast abscess. ${ }^{1-34}$

\section{PHYTOCHEMISTRY}

The important phytochemical contents are flavonoids (rutin, heperoside, and quercetin), steroid, glycoside, tannin, saponin, chlorophyll and nontoxic alkaloid. ${ }^{3,16}$ Indonesia's National Agency of Drug and Food Control (BPOM) revealed that G. pictum contains alcohol, pectin, and formic acid. Moreover, the essential oil content is not less than $0.4 \%$ and flavonoid $(0.4 \%)$, vomifoliol, a triterpenoid compound, as a chemical marker. ${ }^{8}$ Budiaji et al ${ }^{6}$ reported that G. pictum also contain compounds such as Hexadecanoic acid, ethyl ester; (2E) - 3,7,11,15-tetramethyl-2-hexadecem-1-ol; Pyridine-3-carboxamide, oxime, N- (2-trifluoromethylphenyl); 9-Tricosene; Squalene; Gamma.Tocopherol, Stigmasterol; Beta-sitosterol; 2,5,9-cyclotetradecatrien-1ol, 2,6,10- trimethyl-13- (1-methylethenyl).

\section{PHARMACOLOGICAL ACTIVITIES}

\section{Antibacterial activity}

$0.5 \mathrm{cc}$ of $\mathrm{G}$ pictum extract with different concentrations of $100 \%$, $50 \%, 25 \%, 12.5 \%, 6.25 \%, 3.12 \%, 1.56 \%, 0.78 \%, 0.39 \%, 0.19 \%, 0.019 \%$, $0.04 \%$ and $0.02 \%$ showed inhibition of Streptococcus mutant growth. ${ }^{19}$ Minimum Inhibition Concentration (MIC) of G pictum ethanol extract to Staphylococcus aureus was $25 \mathrm{mg} / \mathrm{ml}$, whereas MIC to Pseudomonas aeruginosa was $50 \mathrm{mg} / \mathrm{ml}^{7,35}$ The gel preparation of the formula (carbopol 940 and CMC-Na $(0.25: 0.75)$ had the best physical and stability properties for 21 days of storage as well as the $9.67 \mathrm{~mm}$ antibacterial inhibitory zone of Staphylococcus aureus. ${ }^{32}$ The ethyl acetate fraction of $\mathrm{G}$ pictum's ethanol extract has the most active antibacterial activity against S. aureus ATCC 25923 with an MKC value of $12.5 \%$ compared to $n$-hexane, ethyl acetate, and water fractions from the ethanol extract purple leaf. ${ }^{17,31}$ When examined against E Coli, the ethyl acetate was the most active fraction compared to n-hexane, ethyl acetate, and water fractions from the ethanol extract purple leaf and the diameter of the inhibition zone on the ethyl acetate fraction in the $50 \%$ concentration is $23,3 \mathrm{~mm} ; 24 \mathrm{~mm}$ and $23 \mathrm{~mm}$. The test for the antibacterial activity with the dilution method shows that the MBC (Minimal Bactericidal Concentration) is $12.5 \% .^{15}$

The extract of leaf $\mathrm{G}$ pictum in a boiled mouthwash of patients using orthodontic appliances showed $40 \%$ reduction of the amount colony of Staphylococcus sp, however, the reduction effect was similar to Chlorhexidine $0.2 \% .{ }^{33}$ Minimum concentration of $12.5 \%$ of methanol extract of $\mathrm{G}$ pictum leaf showed inhibition of growth of root canal bacteria which is polymicrobial and $25 \%$ concentration of $\mathrm{G}$ pictum leaf of methanol extract demonstrated the similar effect of sodium hypochlorite as an antibacterial irrigation agent. ${ }^{11}$ When examined against Enterococcus faecalis, MIC of ethanol G pictum extract was $25 \%$ concentration with $\mathrm{MBC}$ was at $50 \%$ concentration of $\mathrm{G}$ pictum extract. ${ }^{5}$ There was a study which compared the betadine gurgle with $90 \%$ concentration of $\mathrm{G}$ pictum leaf extract as a mouth wash and this study resulted in that $G$ pictum extract leaf had an effect of decreasing saliva viscosity and lowering saliva $\mathrm{pH}$ and thus might prevent the growth of Streptococcus mutans that encourage caries dentis. ${ }^{18}$

\section{Antifungi activity}

The $50 \%$ ethyl acetate fraction of the G pictum was the most active fraction with a $28 \mathrm{~mm}$ in diameter and with dilution test capable of showing MBC to $12.5 \%$ on Candida albicans ATCC $10231 .{ }^{4}$ A clinical trial in 10 patients with oral candidiosis demonstrated that there was a decrease in hypha and spore of patients using $25 \% \mathrm{G}$ pictum leaf mouthwash. ${ }^{37} 40 \%$ of ethanol extract of $\mathrm{G}$ pictum leaf showed the smallest number of growth of Candida albicans in 40 samples of acrylic resin denture. ${ }^{36}$

\section{Immunomodulator activity}

$2.5 \%$ ethanol extract of $\mathrm{G}$ pictum leaf showed enhancement of phagocytosis activity to Candida albicans and the effect was greater than isoprinosine (a synthesis immunomodulator drugs). ${ }^{13} \mathrm{~A}$ report from Kusumawati et al showed the ethanol extract of $G$ pictum to phagocytosis and immunoglobulin $\mathrm{M}$ and TNF- $\alpha$ to the mice's macrophage. ${ }^{14} \mathrm{G}$ pictum leaf ethanol extract $3.125 \%, 6.25 \%, 12.5 \%$, and $25 \%$ concentration showed a decrease of Streptococcus mutans adhesion to neutrophil isolate from healthy individuals in vitro. The higher concentrate of $\mathrm{G}$ pictum leaf ethanol extract demonstrated the smallest number of Streptococcus mutans adhered to neutrophil. ${ }^{19,23}$

\section{Antioxidant activity}

G. pictum leaf extract reduces nephrotoxicity induced by gentamicin via impending lipid peroxidation and ameliorating glutathione content and activity of enzymes in the liver and kidney. Healthy adult Wistar albino rats ( 150 to $250 \mathrm{~g}$ ) aged 60 to 90 days received G. pictum ethanol extract at $300 \mathrm{mg} / \mathrm{kg}, 150 \mathrm{mg} / \mathrm{kg}$, and $75 \mathrm{mg} / \mathrm{kg}$ along with gentamicin and the glutathione (GSH) and Glutathione S-transferases (GST) blood levels were significantly raised. ${ }^{30}$

\section{Antiinflammatory activity}

$G$ pictum leaf ethanol extract exerted inhibition of edema induced by carrageenan in hind paw's mice and this herb also increased the vascular permeability induced by acetic acid. This concluded that $G$ 
pictum exerted an inflammatory effect or the early exudative phase of inflammation..$^{20} 20 \%$ ethanol-extracted cream of $\mathrm{G}$ pictum exerted an anti-inflammatory activity to the white male mice that had been induced inflammation using carrageenan. ${ }^{27}$

\section{Wound healing activity}

Mice back that incised treated with $10 \%$ and $15 \%$ ethanol extract of $\mathrm{G}$ pictum leaf showed the healing of the wound from the dryness of wound, skin crusts , and release of skin crusts. ${ }^{1}$ A study on Wistar rat as reported by Prasetyo et al. revealed that ethanol extract of G. pictum at the dose of $100 \mathrm{mg} / \mathrm{kg}$ significantly attenuated anal ulcer by decreasing the total percentage of ulcer area, edema, leukocyte infiltration as well as malondialdehyde, and at the same time increased the superoxide dismutase as compared to the negative control. ${ }^{17}$

\section{Analgetic property}

Pain is a protective response of the body to the stimulus that is caused by actual or potential tissue damage. This response is associated with a localized or generalized unpleasant feeling that is transmitted to the brain by sensory neurons. As a complex pharmacological condition, there are various options for the treatment of pain. One of the currently prominent therapy for pain is using medicinal plants such as G. pictum.

In vivo study of the analgesic effect of ethanol extract of G. pictum leaves in Swiss Webster female mice by heat-induced method showed that the extract at the doses of 100 and $200 \mathrm{mg} / \mathrm{kg}$ significantly increased the reaction time by the values of 4.62 and 5.15 seconds compared to negative control with the value of 3.59 seconds $(p<0.05)$. Moreover, it was comparable to the positive control (acetosal $0.42 \mathrm{mg} / \mathrm{kg}$ ) with a reaction time of 5.83 seconds $(p>0.05){ }^{25}$

$\beta$-sitosterol isolated from $\mathrm{n}$-hexane fraction of G. pictum leaves was given orally to male mice to investigate its analgesic activity in the writhing reflex model. The compound at the doses of 1,2 , and 4 $\mathrm{mg} / 20 \mathrm{~g}$ was found to inhibit acetic acid-induced pain by the value of $51.2 \%, 64.7 \%$, and $72.3 \%$ respectively. However, the analgesic activity of fractions was lower than aspirin as the positive control. ${ }^{10}$

\section{Anti-haemorrhoid activity}

A recent study by Hutagalung on male Wistar rats induced by $6 \%$ croton oil on the anus for 3 days to develop the haemorrhoid-like condition. Furthermore, G. pictum extract was given orally to the rats at a dose of $100 \mathrm{mg} / \mathrm{kg}$ on day 4 for 5 consecutive days. The result showed that the extract exhibited the anti-hemorrhoid effect by decreasing anal edema measured by the rectoanal coefficient as well as the number of extra vessels leukocyte. The rats that were treated with G. pictum extract experience a less severe anal edema with a rectoanal coefficient that was significantly lower than control group with values of 2.46 and 3.13 respectively. Moreover, the number of extra vessels leukocytes of the treatment group (900.14) was also significantly lower than the control group (1003.28). ${ }^{10}$

\section{Anti-diabetic effect}

The aqueous extract of G. pictum was administered orally to alloxaninduced diabetic Sprague-Dawley rats once a day. The group treated by G. pictum extract exhibited anti-diabetic activity by lowering blood glucose level at a dose of $100 \mathrm{mg} / \mathrm{kg}$ which is comparable to metformin $(10 \mathrm{mg} / \mathrm{kg})$ as the positive control. ${ }^{15}$

Similar to the previous study, Rosmiati and Fernando ${ }^{22}$ reported that $G$. pictum ethanol extract at a dose of $250 \mathrm{mg} / \mathrm{kg}$ successfully decreased blood glucose level of alloxan-induced diabetic male mice as effective as the positive control group that treated with glibenclamide.

Four extracts of G. pictum that were obtained from sequential extraction using ethanol, diethyl ether, ethyl acetate, and butanol to investigate their anti-diabetic effects in alloxan-induced diabetic Sprague-Dawley rats. The extracts were given orally to the rats at a dose of $50 \mathrm{mg} / \mathrm{kg}$ for 28 days of the experiment. The result revealed that all extracts decreased blood glucose level with a percentage of decrease ranging from 30 to $37 \%$ compared to glibenclamide $(0.25 \mathrm{mg} / \mathrm{kg})$ with a value of $56 \%{ }^{19}$

\section{Estrogenic effects ${ }^{24}$}

Oral treatment with hexane leaf extract of G. pictum $(0.5 \mathrm{mg} / 0.05 \mathrm{ml}$ olive oil) possessed an estrogenic effect by significantly increasing the diameter of the uterus, mucous layer thickness, lumen epithelial cell height, and glandular epithelial cell height compared to aquadesttreated group. However, the estrogenic effect of G. pictum remains significantly lower than Ethinyl estradiol as the positive control. ${ }^{27}$

\section{Another research on calcium level}

A research to evaluate the effect of $G$ pictum extract on calcium level on mice femoral bone post ovariectomy proved that $\mathrm{G}$ pictum leaf extract was able to increase the calcium content of the femur. This extract does not affect bone morphometry. This research also showed the optimal dose of $\mathrm{G}$ pictum extract is $30 \mathrm{mg} / \mathrm{kgBW}^{25}$

\section{CONCLUSSION AND FUTURE DIRECTION}

Herein, we documented the existing phytochemistry and pharmacological properties of G. pictum. This plant is a potential herbal therapy for many ailments. A peruse of available scientific references show that the traditional medical uses of G. pictum have been evaluated by modern pharmacological studies such as for anti-hemorrhoid, antimicrobial, anti-inflammation, anti-analgesic, and wound healing, etc., which can be explained by the presence of various compounds such as flavonoids, steroids, terpenoids, anthocyanins, etc. The biological activities and bioactive compounds must be of great attention to the researchers. However, future studies are necessary to address issues regarding the composition of the extract, toxicity, explicability of preclinical experiments, and lack of transformation of the preclinical results to clinical efficacy. Therefore, it is extremely important to conduct detailed investigations on the phytochemical and pharmacological, and toxicity properties and develop standardized formulations based on the ingredients.

\section{ACKNOWLEDGMENT}

Special appreciation to Dr.Agneta Irma Rahayu for support in writing the article and also to the university for helding an international writing publication workshop before submitting this article.

\section{REFERENCES}

1. Andiyani R, Yuniarni U, Mulyanti D. Uji Efektivitas Ekstrak Daun Wungu (Graptophyllum pictum (L.) Griff) Sebagai Penyembuh Luka. 2015

2. ANST. Tanaman obat tradisional II. Jogjakarta: Kanisius; 1992.

3. Aulia Z, Khamid MN, Aninjaya MJSDK. Analisis kandungan flavonoid ekstrak etanol $70 \%$ simplisia daun ungu (graptophyllum pictum I griff.) Dengan metode kromatografi lapis tipis densitometri. 2018;10(2):818.

4. Ayuningtyas M. UJI AKTIVITAS ANTIJAMUR FRAKSI n-HEKSAN, ETIL ASETAT DAN AIR DARI EKSTRAK ETANOLIK DAUN UNGU (Graptophyllum pictum (L.) Griff) TERHADAP Candida albicans ATCC 10231, Universitas Setia Budi Surakarta; 2017.

5. AZIZAH IN. DAYA ANTIBAKTERI EKSTRAK DAUN UNGU (Graptophyllum pictum) TERHADAP BAKTERI Enterococcus faecalis (Penelitian Eksperimental Laboratoris), UNIVERSITAS AIRLANGGA; 2012

6. Budiaji A, Ismail, Nani HJIJOHM, RESEARCH-IJHMCR C IDENTIFICATION COMPOUND CONTAINED IN EXTRACT NI ETHANOL LEAF WUNGU (Graptophyllum Pictum (L.) Griff). 2018;3(3):961-4. 
7. Fauzi D, Sidharta B, Purwijantiningsih LJSFTUAJY. Aktivitas Antibakteri Ekstrak Daun Ungu (Graptophyllum pictum L.) Terhadap Staphylococcus aureus dan Pseudomonas aeruginosa. 2016.

8. Handayani S. Baru 18 Obat Herbal yang Diakui BPOM, Ini Daftarnya. https://www.netralnews.com/news/kesehatan/read/112992/baru-18obat-herbal-yang-diakui-bpom-ini-daftarny.

9. Hariana HA. Tumbuhan Obat \& Khasiatnya 3. Niaga Swadaya; 2008.

10. Hutagalung MSBJJoB, Research T. Phlebotrophic Effect of Graptophyllum Pictum (L.) Griff on Experimental Wistar Hemorrhoids. 2019;5(1):1-4

11. Indriana RA, Astuti $P$, Kurniawati AJe-JPK. Uji Daya Hambat Ekstrak Metanol Daun Ungu (Graptophillum pictum (L.) Griff) terhadap Pertumbuhan Bakteri Saluran Akar Gigi (Inhibition Test of Purple Leaf (Graptophillum pictum (L.) Griff) Methanol Extract toward Root Canal Bacteria's Growth). 2017:5(1):145-50.

12. Khare CP. Indian medicinal plants: an illustrated dictionary. Springer Science \& Business Media; 2008

13. Kurniawati AJDJKG. Pengaruh ekstrak etanol daun ungu (EEDU) Graptophyllum pictum L. Griff terhadap aktivitas fagositosis monosit yang dipapar Candida albicans. 2019;12(2):126.

14. Kusumawati IJD, Fakultas Pasca Sarjana Universitas Airlangga Surabaya. Pengaruh ekstrak etanol daun ungu terhadap fungsi fagositosis serta pembentukan imunoglobulin M dan TNF alpha pada mencit. 2002:32-64.

15. Malahati A. UJI AKTIVITAS ANTIBAKTERI FRAKSI n-HEKSAN, ETIL ASETAT DAN AIR DARI EKSTRAK ETANOL DAUN UNGU (Graphtophyllum pictum (L.) Griff.) TERHADAP Escherichia coli ATCC 25922, Universitas Setia Budi Surakarta; 2017.

16. Manoi F. Analisa fitokimia dan kandungan bahan aktif dari lima aksesi tanaman handeuleum (Graptophyllum pictum (L.) Griff). J Jurnal Penelitian Pertanian Terapan. 2011;11(1).

17. Muhtar RJAIR-AC. UJI DAYA HAMBAT ANTIBAKTERI EKSTRAK DAUN UNGU (Graptophyllum pictum (L.) Griff.) TERHADAP PERTUMBUHAN BAKTERI Staphylococcus aureus SEBAGAI BAHAN PENGAYAAN PRAKTIKUM MIKROBIOLOGI. 2017:1-10.

18. Ningsih W. PENGARUH EKSTRAK DAUN UNGU (Graptophillum Pictum (L.) Griff) SEBAGAI OBAT KUMUR TERHADAP VISKOSITAS SALIVA PADA MAHASISWA ASRAMA JURUSAN KEPERAWATAN GIGI, Poltekkes Kemenkes Yogyakarta Jurusan Keperawatan Gigi; 2020.

19. Nisa TH, Prakoso TPD. Inhibition of Streptococcus Mutant Growth by Purple Leaf Extract (Graptophyllum pictum). Paper presented at: PROSIDING SEMINAR NASIONAL \& INTERNASIONAL2017.

20. OZAKI Y, Sekita S, SOEDIGDO S, Harada M. Antiinflammatory effect of Graptophyllum pictum (L.) Griff. J Chemical pharmaceutical bulletin. 1989;37(10):2799-802.

21. Poh-Yen K, Lay-Jing S, Hanani FJJoAPS. In vitro evaluation of photoprotective potential of the different solvent extracts of Graptophyllum pictum leaves. 2018;8(01):147-51.
22. Quiros-Moran D. Guide to Afro-Cuban Herbalism. Authorhouse; 2009.

23. Rahmah AN. PERAN EKSTRAK DAUN WUNGU (Graptophyllum pictum (L.) Griff) TERHADAP ADHESI Streptococcus mutans PADA NEUTROFIL. 2018.

24. Rahmi H. The Activity of Wungu Leaf (Graptophyllum pictum (L) Griff) Extract in Reducing Blood Glucose Level of Hyperglycemic Mice. Current Biochemitry. 2014; vol 1 (2).

25. Rakasiwi HL, Suhargo L, Sugiharto. The effect of Graptophyllum pictum (L.) Griff leaf extract on morphometry and calcium levels of ovariectomized mice femur. Paper presented at: AIP Conference Proceedings2019.

26. Ramawat KG, Mérillon J-M. Bioactive molecules and medicinal plants. Springer; 2008.

27. Rikomah SE, Elmitra AOM. Effectiveness Test of Anti-Inflammation of Ethanol-Extracted Cream of Graptophyllum pictum L. Griff on White Male Mice (Mus musculus)

28. Salim Z, Munadi E, Nugroho R. Info komoditi tanaman obat. 2017:1-2.

29. Singh P, Khosa RL, Mishra G, Tahseen MA. A phytopharmacological review on Justicia picta (Acanthaceae): A well known tropical folklore medicinal plant. J J Coastal Life Med. 2015;3(12):1000-2.

30. Srinivasan KK, Mathew JE, D'Silva KJA, Lobo R, Kumar N. Nephroprotective potential of Graptophyllum pictum against renal injury induced by gentamicin. J Iranian Journal of Basic Medical Sciences. 2015;18(4):412.

31. Suryaku NI. UJI AKTIVITAS ANTIBAKTERI FRAKSI n-HEKSAN, ETIL ASETAT DAN AIR DARI EKSTRAK ETANOLIK DAUN UNGU (Graptophyllum pictum (L.) Griff) TERHADAP Staphylococcus aureus ATCC 25923, Universitas Setia Budi Surakarta; 2017.

32. Syaiban S. FORMULASI GEL HAND SANITIZER EKSTRAK DAUN UNGU (Graphtophyllum pictum (L.) Griff) DENGAN VARIASI BASIS CARBOPOL 940 DAN CMC-Na SERTA UJI AKTIVITAS TERHADAP BAKTERI Staphylococcus aureus ATCC 25923, Universitas Setia Budi Surakarta; 2017.

33. Tayoh A. Pengaruh Kumur Rebusan Daun Wungu (Graptophyllum Pictum (L) Griff) Terhadap Jumlah Koloni Bakteri Staphilococcus SP Dalam Saliva Pada Pemakai Alat Orthodonsi Cekat. Jember, Middle Java: FAculty of Dentirsy, Universitas Jember, Jember; 2006.

34. Turner IM. A catalogue of the Annonaceae of Borneo. J phytotaxa. $2011 ; 36(1): 1-120$.

35. Ummanah C. Uji Skrining Fitokimia Dan Antimikroba Ekstrak Daun Handeuleum (Graptophyllum pictum L. Griff.) Dalam Menghambat Pertumbuhan Mikroba Patogen. 2017.

36. Wahyuningtyas E. Pengaruh ekstrak Graptophyllum pictum terhadap pertumbuhan candida albicans pada plat gigi tiruan resin akrilik. Journal of Dentistry Indonesia. 2008;15(3):187-191.

37. Wulandari B. Pengaruh Pemberian Perasan Daun Ungu (graptophyllum pictum (I) griff) terhadap Jumlah Hifa dan Spora Candida Albicans pada Penderita Oral Candidiasis dengan Faktor Predisposisi Stres. Skripsi Fakultas Kedokteran Universitas Jember. 2008.

Cite this article: Makkiyah F, Rahmi EP, Revina R, Susantinigsih T, Setyaningsih Y. Graptophyllum pictum (L.) Griff. (Syn: Justicia picta Linn.) and its Effectiveness: A Well-Known Indonesian Plant. Pharmacog J. 2021;13(3): 835-8. 